\title{
Toxic Indoor Air Is a Potential Risk of Causing Immuno Suppression and Morbidity-A Pilot Study
}

\author{
Kirsi Vaali ${ }^{1, *}$, Marja Tuomela ${ }^{2,3}$, Marika Mannerström ${ }^{4}$, Tuula Heinonen ${ }^{4}$ and Tamara Tuuminen ${ }^{5}$ \\ 1 SelexLab Oy, Kalevankatu 17 A, 00100 Helsinki, Finland \\ 2 Co-op Bionautit, Viikinkaari 9, 00790 Helsinki, Finland; marja.tuomela@helsinki.fi \\ 3 Department of Microbiology, University of Helsinki, 00014 Helsinki, Finland \\ 4 The Finnish Centre for Alternative Methods, Faculty of Medicine and Health Technology, Tampere University, \\ Arvo Ylpön katu 34, 33014 Tampere, Finland; marika.mannerstrom@tuni.fi (M.M.); \\ tuula.heinonen@tuni.fi (T.H.) \\ 5 Medical Center Kruunuhaka Oy, Kaisaniemenkatu 8B a, 00100 Helsinki, Finland; tuuminen@gmail.com \\ * Correspondence: kvaali43@gmail.com; Tel.: +358-50-550-1131
}

check for updates

Citation: Vaali, K.; Tuomela, M.; Mannerström, M.; Heinonen, T.; Tuuminen, T. Toxic Indoor Air Is a Potential Risk of Causing Immuno Suppression and Morbidity-A Pilot Study. J. Fungi 2022, 8, 104. https:// doi.org/10.3390/jof8020104

Academic Editor: Laurent Dufossé

Received: 22 November 2021

Accepted: 4 January 2022

Published: 21 January 2022

Publisher's Note: MDPI stays neutral with regard to jurisdictional claims in published maps and institutional affiliations.

Copyright: (C) 2022 by the authors. Licensee MDPI, Basel, Switzerland. This article is an open access article distributed under the terms and conditions of the Creative Commons Attribution (CC BY) license (https:// creativecommons.org/licenses/by/ $4.0 /)$.

\begin{abstract}
We aimed to establish an etiology-based connection between the symptoms experienced by the occupants of a workplace and the presence in the building of toxic dampness microbiota. The occupants (5/6) underwent a medical examination and urine samples (2/6) were analyzed by LC-MS/MS for mycotoxins at two time-points. The magnitude of inhaled water was estimated. Building-derived bacteria and fungi were identified and assessed for toxicity. Separate cytotoxicity tests using human THP-1 macrophages were performed from the office's indoor air water condensates. Office-derived indoor water samples $(n=4 / 4)$ were toxic to human THP-1 macrophages. Penicillium, Acremonium sensu lato, Aspergillus ochraceus group and Aspergillus section Aspergillus grew from the building material samples. These colonies were toxic in boar sperm tests $(n=11 / 32)$; four were toxic to BHK-21 cells. Mycophenolic acid, which is a potential immunosuppressant, was detected in the initial and follow-up urine samples of $(2 / 2)$ office workers who did not take immunosuppressive drugs. Their urinary mycotoxin profiles differed from household and unrelated controls. Our study suggests that the presence of mycotoxins in indoor air is linked to the morbidity of the occupants. The cytotoxicity test of the indoor air condensate is a promising tool for risk assessment in moisturedamaged buildings.
\end{abstract}

Keywords: indoor air water; dampness and mold hypersensitivity syndrome; mycotoxins; clinical toxicology; sick building syndrome; urine

\section{Introduction}

There is convincing scientific data that the exposure to dampness microbiota and the decay products of construction materials may cause the development of polymorbidities and systemic inflammation [1,2], now collectively called dampness and mold hypersensitivity syndrome (DMHS) [3], although this designation has not yet received official recognition. The causality between the exposure to dampness microbiota (the source) and the clinical outcome (the effect) is still being questioned. Polymorbidity in the occupants of moisture-damaged buildings with indoor air toxicity has been extensively studied in Finnish schoolchildren and the occupants of a moisture-damaged hospital and a police station [1,4-8]. These studies have demonstrated that the prolonged exposure to dampness microbiota and the decay products of a building's construction materials may cause a plethora of non-respiratory symptoms such as profound fatigue, neurological, gastrointestinal, and muscular-skeletal problems in addition to the already acknowledged respiratory symptoms. Because no single biomarker to diagnose DMHS has yet been devised, the diagnosis remains clinical and is based on interview. The patients often recall some form of water leakage in their homes or workplaces and a gradual worsening of their symptoms. 
Initially, the symptoms are reversible and related to the so-called sick building syndrome, (SBS) [9]. However, if there is continuous or cumulative exposure (e.g., starting already in the kindergarten, and then in school, high school and then workplaces) the symptoms may become aggravated and progress into irreversible multi-organ DMHS [3]. Importantly, DMHS is associated with an increased rate of respiratory infections [3] probably indicating decreased immunologic tolerance to environmental viruses and bacteria. Moreover, deprivation of the immune system has been proposed by us when reviewing the long-term morbidity among the occupants of one of the moisture-damaged school [10]. A higher prevalence of different oncological diseases, unexplained succeptibility to sepsis and a higher than normal rate of autoimmune diseases have been reported [10].

The investigations of the indoor air quality do not always recognize existing problems within buildings; for example, the impact of air toxicity has been overlooked. Most of the toxic metabolites produced by fungi or bacteria recovered from moisture-damaged buildings have a molecular weight of 300-2000 g/mol, i.e., they are non-volatile. However, mycotoxins may be present in indoor air either attached to fungal spores or to fragments of these microorganisms, e.g., broken or fractured conidia and hyphae. These particles may remain suspended in the air for a long time [11]. Recently, it was reported [12-14] that some species of dampness microbiota produce vesicles, or the so-called "guttation droplets", or exudates on a culture dish. These droplets may contain substances which are toxic to eukaryotic cell types at dilutions of 1/100-20,000 [12,15,16]. The most efficient solvents for mycotoxins are relatively polar solvents, such as methanol or ethanol, only a few mycotoxins are water soluble [17]. The relative humidity ( $\mathrm{RH} \%)$ of the air becomes elevated when the environment is crowded with occupants (e.g., schools during the working hours) which allows these droplets to move around aerodynamically and thus the toxins can spread throughout the environment [18]. For example, Penicillium expansum recovered from gypsum boards produced these kinds of toxic droplets, i.e., exudates that were released into the air and were $>100$-times more toxic in the cell culture assays than indoor air isolates of Aspergillus, Chaetomium, Stachybotrys and Paecilomyces [13]. These droplets may represent an even greater health hazard than the spores and nanoparticles of a microbial mass growing in the environment.

To address the issue of air toxicity, we have devised a novel method of collection of indoor air water vapour by adopting a newly patented technique with the so-called E-collector: (US Patent 10,502,722 B2; www.sisailmatutkimuspalvelut.fi, accessed on 21 November 2021) $[18,19]$. Briefly, the air condensate is collected on a cooled surface of a steel plate, the condensate then can be tested for its cytotoxicity against living cells [19]. Boar sperm cells $[20,21]$ or several eukaryotic cell lines, such as porcine kidney cell line (PK-15) $[13,22,23]$ or murine neuroblastoma cells (MNA) $[13,23,24]$, have been used in toxicity studies instead of experiments in production animals. In this publication, we have successfully used boar spermatozoids and baby hamster kidney (BHK) cells for the same purpose.

Here, we describe a plausible pathway of how the mycotoxins present in the indoor air water samples gain access to the exposed individuals. We demonstrate the usefulness of urinalysis for the detection of mycotoxins as biomarkers of DMHS. A novel method [19] for the sampling and testing of indoor air toxicity is presented and shortly discussed.

\section{Materials and Methods}

\subsection{The Patients}

This working community comprised six members, and their work premises which were located partly below ground level in an office building (Figure 1). Within approximately three months after the move into this office, every member of this workplace community started to suffer from symptoms compatible with their exposure to indoor air dampness microbiota. Finally, the symptoms became unbearable. The patients wanted to remain anonymous and therefore their gender and age are not reported. 


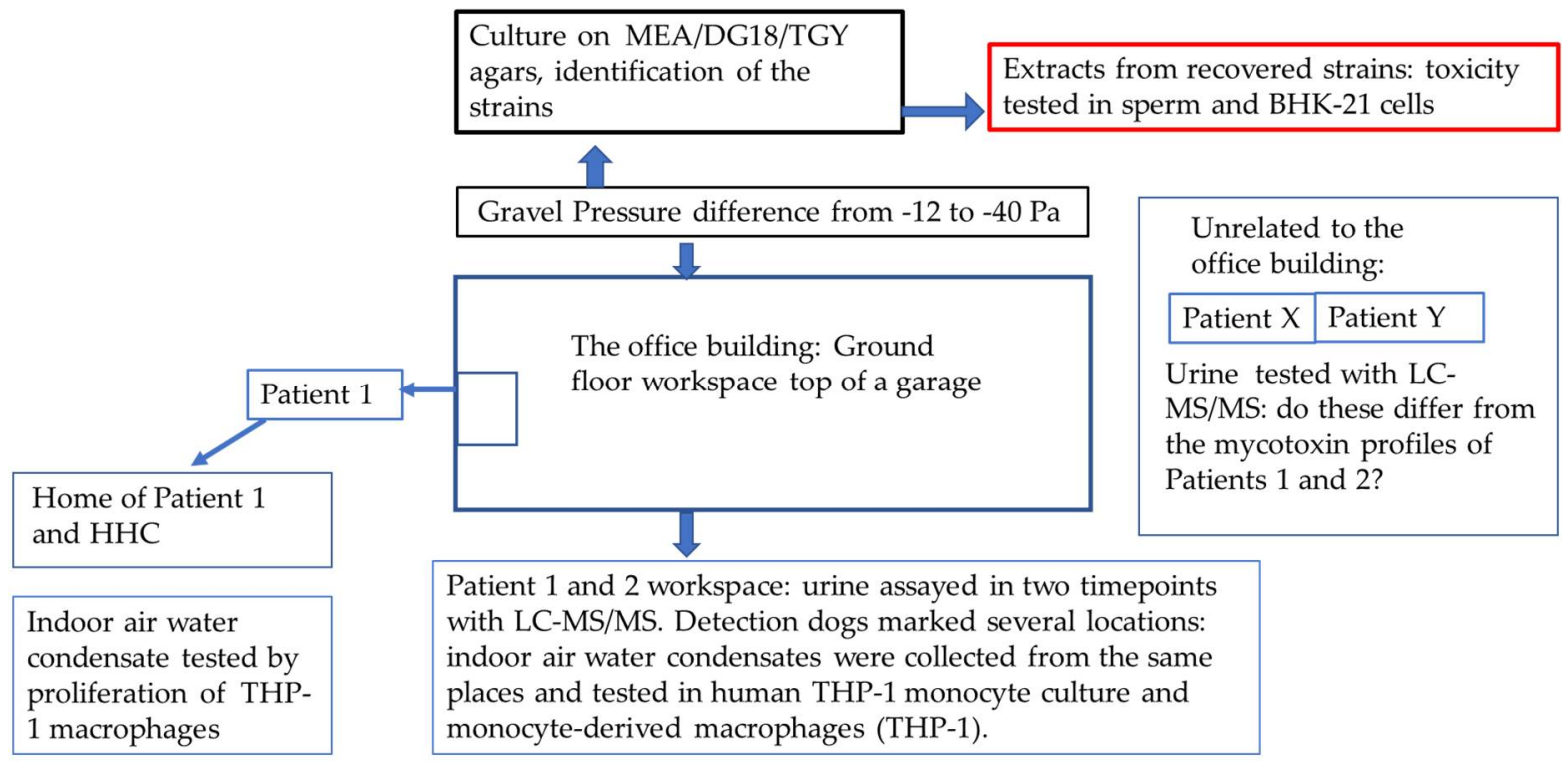

Figure 1. The study design.

Five (Patients 1-5) out of six occupants of the problematic building were examined by one of us (TT) and one (Patient 6) was interviewed over the telephone. All were healthy before the move into the problematic office. Their life histories and the symptoms were recorded during their visits and then retrieved with the patients' written consent.

For comparison of urinalysis profiles, we investigated two unrelated patients (Patient $X$ and $Y$ ) who volunteered to have their urine samples tested because their symptoms were compatible with an exposure to dampness microbiota. They were unrelated to each other, they lived and worked in different cities than the working community in question. Neither microbiological nor toxicological investigations in their homes or workplaces had been performed at the time of our investigation. Patient $\mathrm{X}$ moved with all his/her belongings to a new home but continued to experience a general feeling of sickness, fatigue, and mucosal irritation.

\subsection{Detection of Mycotoxins in the Patients' Urine Samples}

The detection of mycotoxins from the patients' urine was performed in the Great Plains Laboratory Inc. (Lenexa, KS, USA) using a liquid chromatography tandem mass spectrometry (LC-MS/MS) technique. The urine specimens from Patients 1 and 2 of the working community and a sample from a household control (HHC) of Patient 1, and from Patients $X$ and $Y$ were analyzed. Follow-up samples from Patients 1 and 2 were taken 2.5 months later after the working community had moved to a clean building.

The detection of mycotoxins was performed according to the standard operational procedure of the laboratory. The presence of the mycotoxin mycophenolic acid was confirmed after extraction of urine and LC/MS/MS testing of the extract with a deuterated mycophenolic acid internal standard [25], indicating that a peak with all the characteristic ions of authentic mycophenolic acid [26,27] and the identical retention time of mycophenolic acid was present in many patients [28]. In addition, patients with high mycophenolic acid in urine has been tested as positive for mycophenolic acid by a commercial specific immunoassay (Cedia) from ThermoScientific for mycophenolic acid in urine. Mycophenolic acid can be produced by multiple species of Penicillium and other molds [29-31].

\subsection{The Office Building}

The working community had their office located on the ground floor of a building with a cellar. It was built from concrete elements and had a mechanical ventilation system. One of the walls in the office faced a non-heated hollow area which was below the soil 
surface and was lined on the bottom with a layer of gravel and on the top with a closing plate mostly without waterproofing. Thus, water from rain and melting snow had leaked inside the hollow area enabling microbial growth. There were several air leaks in the wall of the office adjacent to the hollow area. Because of the negative pressure difference $(-12 \mathrm{~Pa}$ on average, momentarily even $-40 \mathrm{~Pa}$ ) in the office compared with the hollow area, the air from this area was able to penetrate the office. The hollow area remained moist all year round.

The office was also examined by sniffer dogs which are trained in mold detection. The dogs marked six locations, with five of these being beside the wall facing the hollow area. In some locations, the characteristic odors of microbes were noticeable also to the occupants.

\subsection{Sampling of the Indoor Air Condensate Water}

The device and the technique to collect indoor air water samples have been described elsewhere [19]. Briefly, the principle of the collection is based on the phenomenon of the condensation of water molecules on the top of cold surfaces of metal plates. After melting of the frozen water to room temperature, the condensate is collected from the tray of the device into Eppendorf tubes that are transferred to the laboratory where the condensate is analyzed in a cell culture assay. This collection technique enables the harvesting of airborne toxic substances in indoor air vapor that may contain mycotoxins [13] as well as various large molecules [32].

The condensing water samples from the six locations marked by the sniffer dogs were collected with the E-collector from the office building. Samples were also collected from the home of Patient 1.

\subsection{Indoor Air Toxicity Studies}

The toxicity of the indoor air water condensates collected from different locations of the office and from the home of Patient 1 was studied using the human acute monocytic leukemia cell line (THP-1) using water-soluble tetrazolium salts (WST-1) in a cytotoxicity assay $[19,33]$. The WST-1 assay is an indicator of mitochondrial activity and commonly used to assess cell viability; decreased mitochondrial activity reflects a loss of cell viability, i.e., cell death. Increased mitochondrial activity reflects an increased cell number, i.e., proliferation, or increased cellular respiration induced by mitochondrial uncoupling reactions [34,35]. The WST-1 Cell Proliferation Reagent was obtained from Roche (Basel, Switzerland). Human THP-1 monocytes (Cat. No. TIB-202) were from ATCC (LGC Promochem AB, Boras, Sweden), and were verified to be Mycoplasma-free (MycoAlert ${ }^{\mathrm{TM}}$ kit, Lonza Basel, Switzerland) prior to use. THP-1 monocytes were maintained in RPMI 1640 Medium supplemented with $10 \%$ fetal bovine serum (FBS), and when differentiated to macrophages, challenged with $25 \mathrm{nM}$ phorbol 12-myristate 13-acetate (PMA) (Sigma Aldrich, Steinheim, Germany) for $48 \mathrm{~h}$ followed by a $24 \mathrm{~h}$ recovery period.

The cells were seeded into 96-well plates at a density of $10^{5}$ cells/well and exposed for $24 \mathrm{~h}$ to the indoor air condensates at 10\% and 25\% concentrations (in RPMI supplemented with $5 \%$ FBS). Cells exposed to an equal volume of distilled water (10\% or $25 \%)$ served as negative controls, and to nickel II sulphate hexahydrate $(2.0$ and $20.0 \mu \mathrm{g} / \mathrm{mL})$ as a positive control. All samples and controls were tested in six replicates. In the assessment of cell viability, $10 \mu \mathrm{L} /$ well WST-1 reagent was added to the cells for 2 hours, and subsequently absorbance was read at $450 \mathrm{~nm}$. The absorbance is directly proportional to the mitochondrial activity (cell viability). The absorbances were normalized, i.e., the untreated control was set as $100 \%$, and all other data were calculated relative to the control absorbance as either \% decrease in cell viability (negative values) or \% increase in proliferation (positive values). The statistical significance of the changes compared to the untreated control was tested with Student's $t$-test.

The indoor air condensates from the office were tested using both THP- 1 monocytes and THP- 1 macrophages at a $10 \%$ sample concentration. The condensates from the home 
of Patient 1 were tested at two concentrations, i.e., $10 \%$ and $25 \%$, but using only THP1 macrophages.

\subsection{Detection of Mycotoxins from the Condensed Indoor Air Sample}

A left-over aliquot of $0.5 \mathrm{~mL}$ of the condensed indoor air water sample in the Eppendorf tube was sent at ambient temperature for LC-MS/MS analysis to the Great Plains laboratory. This sample had not been stored protected from light.

\subsection{Indoor Air Relative Humidity Measurements and Estimation of Respiratory Mycotoxin Exposure}

The relative humidity was measured with Gann Hydromette BL RH-T (Gann Messu. Regeltechnik GmbH, Gerlingen, Germany). To show the probability of the inhalation exposure route instead of the more improbable oral exposure, we estimated the amount of water inhaled in the prevailing indoor air conditions (Table 1). The estimation is approximately $14-15 \mathrm{~g}(\mathrm{~mL})$ of inhaled water/day, resulting in a challenge of 730-760 $\mathrm{g}$ of water/2.5 months exposure time.

Table 1. Estimation of the inhaled water during the stay in a problematic building.

\begin{tabular}{cccccccc}
\hline & $\begin{array}{c}\text { Inhaled Air } \\
\text { Vol (L) }\end{array}$ & $\begin{array}{c}\text { Number of } \\
\text { Inhalations }\end{array}$ & $\begin{array}{c}\text { Inhaled } \mathbf{m}^{\mathbf{3}} \\
\text { of Air/ } \mathbf{~ h}\end{array}$ & RH (\%) & Temp $\left({ }^{\circ} \mathbf{C}\right)$ & $\begin{array}{c}\text { Humid } \\
\text { Ratio }\end{array}$ & $\begin{array}{c}\text { Inhaled Water/8 h/mL/g } \\
\text { Water }\end{array}$ \\
\hline Space 1 (Pat 1) & 0.5 & 13 & 3.12 & 30.8 & 21.4 & 4.877 & 15.22 \\
\hline Space 2 & 0.5 & 13 & 3.12 & 30.2 & 21.4 & 4.781 & 14.92 \\
\hline Space 3 & 0.5 & 13 & 3.12 & 30.6 & 21.6 & 4.905 & 15.30 \\
\hline Space 4 (Pat 2) & 0.5 & 13 & 3.12 & 29.1 & 21.6 & 4.663 & 14.55 \\
\hline
\end{tabular}

The estimated volume of inhaled air by adults is $0.5 \mathrm{~L} /$ inhalation, the frequency of inhalations was estimated to be 13 times/min (the average 12-16 times/min, depending on the physical activity). The estimated frequency of inhalations is $13 / \mathrm{h}$ in office workers. The humid ratio was calculated from the measured relative humidity $(\mathrm{RH})$ and room temperature $\left({ }^{\circ} \mathrm{C}\right)$, according to the formula: available online: http:/ / www.flycarpet.net/ en/PsyOnline (accessed on 21 November 2021).

\subsection{Collection of a Sample for Microbiological Analysis}

A gravel sample was collected from the hollow area in the proximity of the floor of the office. There was no visible fungal growth in the sample. The sample was cultured on three agar media, namely malt extract (MEA) with the following formulations: malt extract, $20 \mathrm{~g}$; agar, $15 \mathrm{~g}$; and distilled water to 1 liter [36], dichloran-glycerol (DG18) with the following formulation: glucose, $10 \mathrm{~g}$; bacteriological peptone, $5 \mathrm{~g}$; $\mathrm{KH}_{2} \mathrm{PO}_{4}, 1.0 \mathrm{~g} ; \mathrm{MgSO}_{4} \times 7 \mathrm{H}_{2} \mathrm{O}$, $0.5 \mathrm{~g}$; agar, $15 \mathrm{~g}$; distilled water to 1 / L; $220 \mathrm{~g}$ of glycerol (analytical reagent grade) having a final concentration of $18 \%(\mathrm{wt} / \mathrm{wt})$; and $1 \mathrm{~mL}$ of a $0.2 \%$ (in ethanol) solution of dichloran (2,6-dichloro-4-nitroaniline) to a final concentration of $2 \mathrm{mg} / \mathrm{L}$ [36] and tryptone glucose yeast extract (TGY) with the following formulation: tryptone, $5.0 \mathrm{~g}$; yeast extract, $2.5 \mathrm{~g}$; glucose, $1.0 \mathrm{~g}$; agar $15 \mathrm{~g}$; and distilled water to $1 \mathrm{~L}$ [37]. All the media were autoclaved for $15 \mathrm{~min}$ at $121^{\circ} \mathrm{C}$, and $\mathrm{pH}$ values for ready medium were 5.5, 5.6 and 7.0, respectively.

Two inoculation methods with two replicates were used for each medium and dilution: (1) Direct inoculation on the agar plates $(0.5 \mathrm{~g} / \mathrm{plate})$. (2) Serially diluted suspensions from the sample were pipetted onto agar plates $(0.1 \mathrm{~mL} /$ plate) according to the instructions of National Supervisory Authority for Welfare and Health in Finland [38,39]. The composition of the diluent is as follows: $0.0425 \mathrm{~g} \mathrm{KH}_{2} \mathrm{PO}_{4}, 0.25 \mathrm{~g} \mathrm{MgSO} 4 \times 7 \mathrm{H}_{2} \mathrm{O}, 0.008 \mathrm{~g} \mathrm{NaOH} / 1 \mathrm{~L}$ deionized water. The diluent was prepared as follows: adjusted to $\mathrm{pH} 7.0 \pm 0.2 ;$ add $0.2 \mathrm{~mL}$ Tween 80 as the detergent, then autoclaved at $121^{\circ} \mathrm{C}, 15 \mathrm{~min}$. The plates were incubated at room temperature and the cultures were examined after one, two or three weeks with the fungal genera being identified by microscopy [40-43], and furthermore Aspergillus spp. 
was identified at a species or section level [44]. The fungal identification was based on the inspection of the morphology as recommended by the Finnish authorized bodies, although the current nomenclature has been recently changed in accordance with the advances in molecular methods [38]. The bacterial colonies were counted and Streptomycetes were identified [38].

\subsection{Detection of Toxicity from the Microbial Growth}

The colonies of all the fungal and bacterial species $(n=32)$ that grew on the agar plates were tested in the boar sperm test according to Andersson et al. [20] and Castagnoli et al. [21], and in a mammalian cell test according to Rasimus et al. [45]. A colony or a part of it (20-30 mg) was extracted into $96 \%$ ethanol $(0.2 \mathrm{~mL})$. In the toxicity tests, boar spermatozoa that are used in artificial insemination (Figen Oy, Seinäjoki, Finland) and baby hamster kidney cells (BHK-21 [C13] ATCC ${ }^{\circledR}$ CCL10 ${ }^{\mathrm{TM}}$ ) were exposed to the ethanol extracts $(n=32)$. After incubation with the ethanol extracts, the inhibition of BHK-21 cell growth was assessed using the resazurin reduction assay [46], while toxicity to boar spermatozoa was assessed as a lack of motility observed with the CellSens computer program [21] and visually with a microscope [20]. Pure ethanol was a negative control in both tests. The BHK cells were maintained in Dulbecco's modified Eagle's medium (DMEM) supplemented with $10 \%$ fetal bovine serum (FBS), $2 \mathrm{mM} \mathrm{L}$-glutamine, $100 \mathrm{U} / \mathrm{mL}$ penicillin and $100 \mu \mathrm{g} / \mathrm{mL}$ streptomycin.

\subsection{Ethical Considerations}

All participants of this study provided their written informed consent to use their records.

\section{Results}

\subsection{Clinical Picture in Persons Exposed to Toxic Indoor Air}

The symptoms reported by Patients 1-5 are summarized in Table 2. Patient 6 started to experience a very severe headache that did not become better during the weekends. This person was given a diagnosis of tension neck, and the symptoms were not interpreted as being associated with an exposure to poor indoor air quality. The patient was often on sick leave and changed the workplace before this investigation started. The work ability returned after changing the employer, and the headache did not reappear.

Table 2. The symptoms experienced by the working community. The symptoms often reported by patients with chronic mold illness are marked with *

\begin{tabular}{|c|c|c|c|}
\hline & Patient's History & Symptoms & Findings during the Visit \\
\hline \multirow[t]{11}{*}{ No 1} & $\begin{array}{l}\text { No previous exposure to } \\
\text { dampness microbiota }\end{array}$ & * Irritation of eyes & \multirow{11}{*}{$\begin{array}{l}\text { * Symptoms became worse when } \\
\text { entering the problematic building } \\
\text { * Symptoms did not relieve } \\
\text { during weekends } \\
\text { Status uneventful } \\
\text { The lesions were indurated, } \\
\text { watery and had been scratched } \\
\text { except for dermatitis on hands, } \\
\text { legs, stomach, knees and back }\end{array}$} \\
\hline & \multirow[t]{10}{*}{ No change in the diet } & * Very severe headache & \\
\hline & & *Recurrent sinusitis & \\
\hline & & * Multiple courses of antibiotics & \\
\hline & & * Thermoregulation problems & \\
\hline & & ${ }^{*}$ Itching of the skin & \\
\hline & & * Exanthema & \\
\hline & & * Sore throat & \\
\hline & & ${ }^{*}$ Gastrointestinal reflux for months & \\
\hline & & * "Brain fog" & \\
\hline & & ${ }^{*}$ A flu-like feeling & \\
\hline
\end{tabular}


Table 2. Cont.

\begin{tabular}{|c|c|c|c|}
\hline & Patient's History & Symptoms & Findings during the Visit \\
\hline No 2 & $\begin{array}{l}\text { Lived in a town house with } \\
\text { his/her family } \\
\text { All the other family members } \\
\text { were asymptomatic }\end{array}$ & $\begin{array}{l}\text { * Dyspnoea } \\
\text { * Migraine } \\
\text { * Phlegm } \\
\text { * Muscle pain } \\
\text { * Fatigue } \\
\text { * Concentration problems } \\
\text { * Prolonged cough } \\
\text { * Sleeping problems }\end{array}$ & $\begin{array}{l}\text { * Symptoms had started to ease in } \\
2 \text { weeks if the person was absence } \\
\text { from work } \\
{ }^{*} \text { Large psoriatic lesions especially } \\
\text { on the elbows, back, scalp and } \\
\text { chest, lips were cracked open } \\
\text { * The blood pressure was elevated }\end{array}$ \\
\hline No 3 & $\begin{array}{l}\text { Previously suffered from } \\
\text { gastrointestinal problems } \\
\text { and allergy }\end{array}$ & $\begin{array}{l}\text { * Sore throat } \\
\text { * Blisters on the oral mucosa } \\
\text { * A flu-like feeling } \\
\text { * Blurred vision } \\
\text { * Severe fatigue } \\
\text { * Dyspnea } \\
\text { * Joint pain } \\
\text { Irregular peristaltic action and } \\
\text { menorrhagia }\end{array}$ & $\begin{array}{l}\text { *Redness of eye conjunctiva, } \\
\text { unrelated to season } \\
\text { Exanthema in the lower } \\
\text { neck region }\end{array}$ \\
\hline No 4 & $\begin{array}{l}\text { Gastrointestinal dysbiosis, } \\
\text { leaky gut }\end{array}$ & $\begin{array}{l}\text { * Thermoregulation problems } \\
\text { * Two flu-like episodes } \\
\text { * Increased sputum production }\end{array}$ & $\begin{array}{l}\text { Otherwise, the status uneventful } \\
\text { Axillary temperature } 36.8^{\circ} \mathrm{C} \text {, } \\
\text { exanthema in the lower } \\
\text { neck region }\end{array}$ \\
\hline No 5 & $\begin{array}{l}\text { Previously healthy, the individual } \\
\text { had not been exposed to } \\
\text { dampness and mold }\end{array}$ & $\begin{array}{l}\text { * Two courses of antibiotics for } \\
\text { tonsillitis } \\
* \text { Sore throat } \\
* \text { Evenings: eyes dry and voice hoarse } \\
* \text { Occasional instances of fatigue } \\
* \text { Memory problems }\end{array}$ & Status uneventful \\
\hline No 6 & Did not attend the doctor's office & Was interviewed by telephone & \\
\hline
\end{tabular}

\subsection{Detection of Mycotoxins from the Urine Samples}

The mycotoxin profiles of Patients 1 and 2 and HHC, Patients X and Y, the controls, are shown in Table 3. It is noteworthy that the HHC for Patient 1 showed evidence of the excretion of ochratoxin A in the urine but the profile was different from that of Patient 1 and there was no mycophenolic acid detectable in his/her urine. The LC-MS/MS plots of mycophenolic acid are presented in Figure 2A,B. The mycotoxin profiles of Patients $\mathrm{X}$ and $\mathrm{Y}$ did not contain mycophenolic acid, and were different from those of Patients 1 and 2 who represented the work community exposure cohort. 
Table 3. Detection of mycotoxins in urine by LC-MS/MS.

\begin{tabular}{|c|c|c|c|c|c|c|c|}
\hline $\begin{array}{c}\text { Mycotoxins } \\
\text { Reference Values } \\
\text { in ng/g Creatinine }\end{array}$ & $\begin{array}{l}\text { Patient } 1 \\
\text { First Test }\end{array}$ & $\begin{array}{c}\text { Patient } 1 \\
\text { Follow-Up Test }\end{array}$ & $\begin{array}{l}\text { HHC to Patient } 1 \\
\text { (Time-Point as for } \\
\text { Pat } 1 \text { Follow-Up) }\end{array}$ & $\begin{array}{l}\text { Patient } 2 \\
\text { First Test }\end{array}$ & $\begin{array}{c}\text { Patient } 2 \\
\text { Follow-Up Test }\end{array}$ & Patient X & Patient $Y$ \\
\hline $\begin{array}{l}\text { Aflatoxin M1 } \\
(3.5-20)\end{array}$ & 0 & 0 & 0 & 0 & 0 & 0 & 0 \\
\hline $\begin{array}{c}\text { Ochratoxin A } \\
\qquad(4-20)\end{array}$ & 11.23 & 9.82 & * 63.52 & 7.01 & 10.96 & 8.58 & 18.36 \\
\hline $\begin{array}{l}\text { Gliotoxin } \\
(200-2000)\end{array}$ & 0 & 0 & 0 & 0 & 0 & 0 & * 910.98 \\
\hline $\begin{array}{c}\text { Sterigmatocystin } \\
\quad(0.2-1.75)\end{array}$ & 1.14 & 0 & 0 & 0.74 & 0 & 0 & 0 \\
\hline $\begin{array}{c}\text { Mycophenolic acid } \\
(5-50)\end{array}$ & * 284.64 & 30.45 & 0 & $* 50$ & $* 130.98$ & 17.79 & 7.11 \\
\hline $\begin{array}{l}\text { Roridin E } \\
\quad(1-6)\end{array}$ & 0 & 0 & 0 & 0 & 0 & 0 & 0 \\
\hline $\begin{array}{l}\text { Verrucarin A } \\
(1-10)\end{array}$ & 0 & 0 & 0 & 0 & 0 & 0 & 0 \\
\hline $\begin{array}{c}\text { Enniantin B } \\
(0.07-1)\end{array}$ & $<0.07$ & 0 & 0 & 0 & 0 & 0.43 & 0 \\
\hline $\begin{array}{c}\text { Zearalenone } \\
(0.5-10)\end{array}$ & 0 & 0 & 0 & 4.36 & * 15.54 & 5.55 & 0 \\
\hline $\begin{array}{c}\text { Chaetoglobosin A } \\
(20-80)\end{array}$ & 0 & 0 & 0 & 0 & 0 & 0 & 0 \\
\hline $\begin{array}{l}\text { Citrinin } \\
(10-50)\end{array}$ & $<10$ & $<10$ & 14.9 & 17.47 & 21.56 & 0 & 0 \\
\hline
\end{tabular}

The * indicates excessively high values.

\subsection{Evaluation of the Office before Our Investigations}

In addition to the notable negative pressure difference and air leaks (from -12 to $-40 \mathrm{~Pa}$ ), the assessment of the office revealed insufficient ventilation and a water damaged area in the ceiling covered with gypsum board. The cultured ceiling material contained $10^{7}$ colony forming units/gram (cfu/g) (on MEA plates) or $7 \times 10^{6} \mathrm{cfu} / \mathrm{g}$ of fungi (on DG18 plates), and $3 \times 10^{7} \mathrm{cfu} / \mathrm{g}$ of bacteria (on TGY plates). The identified fungi were Aureobasidium sp. (88-97\%), and yeasts. It should be emphasized that these counts exceed the cut-off values, which are $10^{4}$ for fungi and $10^{5}$ for bacteria [38].

The sniffer dogs marked six locations, five of which were beside the wall facing the hollow area from where a sample was taken for microbiological analysis.

\subsection{Detection of Mycotoxins from the Water Condensate}

After the toxicity studies, a left-over sample from the condensed air was analyzed by the LC-MS/MS. No other peaks of mycotoxins were detected except for mycophenolic acid that was however below the limit of accurate detection. The absence of mycophenolic acid could not be ascertained beyond doubt from the indoor air sample because this sample had not been protected from light and this might have led to the degradation of mycophenolic acid.

\subsection{Toxicity Studies from the Water Condensates}

Toxicity studies from the office's indoor air are shown in Table 4, those from the home of Patient 1 and the HHC are presented in Table 5. All indoor air condensates (tested at a $10 \%$ concentration in the final cell culture test system) collected from the office caused adverse effects on cells: Samples from 2 locations out of 4 induced THP- 1 monocyte proliferation, whereas samples from all 4 locations were toxic to the THP- 1 macrophages. None of the indoor air water condensates collected from the home of Patient 1 and HHC were toxic to THP-1 macrophages tested at the same i.e., $10 \%$ concentration. However, after 
increasing the indoor water condensate amount from $10 \%$ to $25 \%$ in the test system, toxicity was observed in the home of Patient 1 and the HHC. The samples taken from the bedroom located on the 1st floor, and that from the living room located on a 2nd floor induced a slight proliferation of THP-1 macrophages. Samples collected from the home were not tested on THP-1 monocytes, Table 5.

(A)

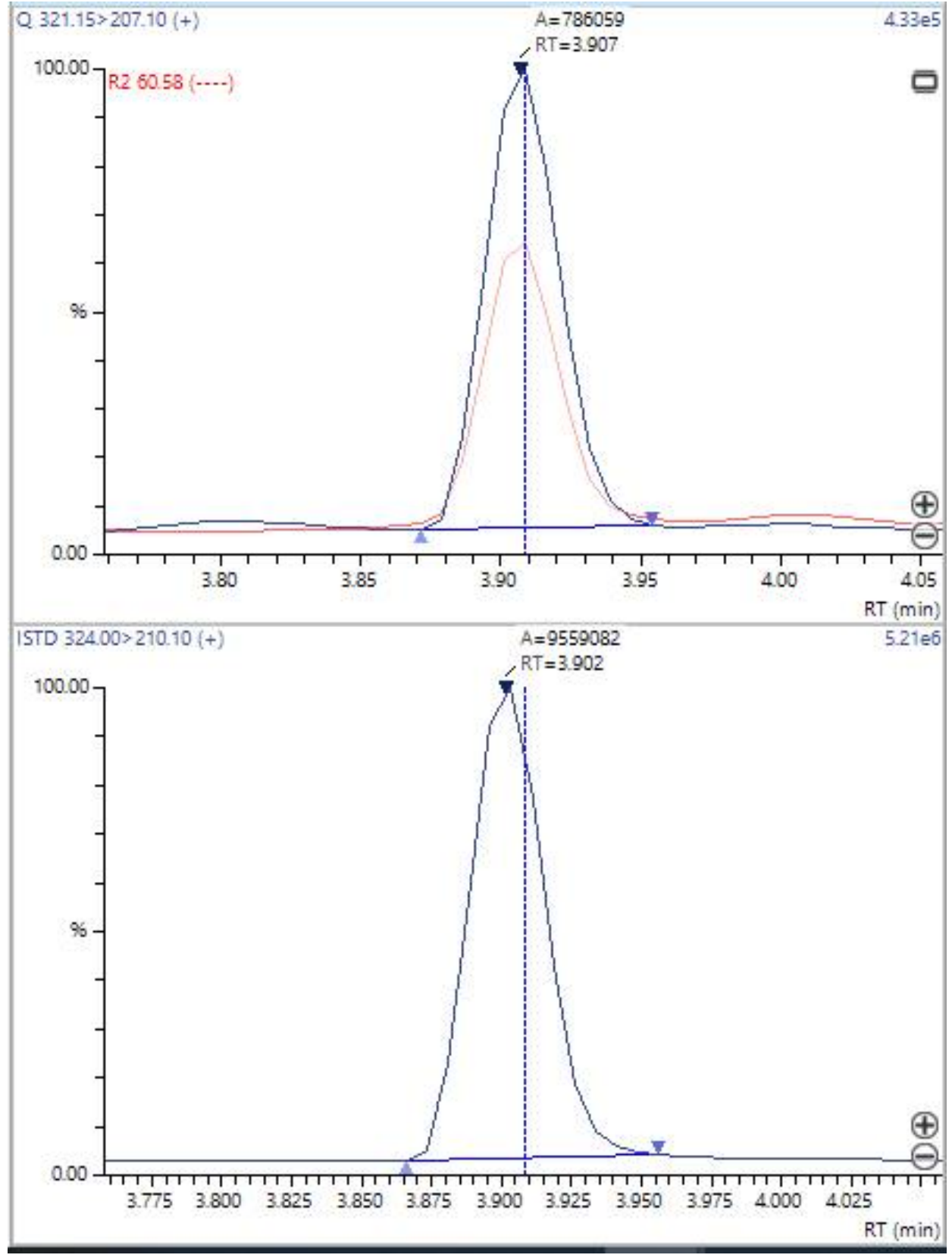

Figure 2. Cont. 
(B)

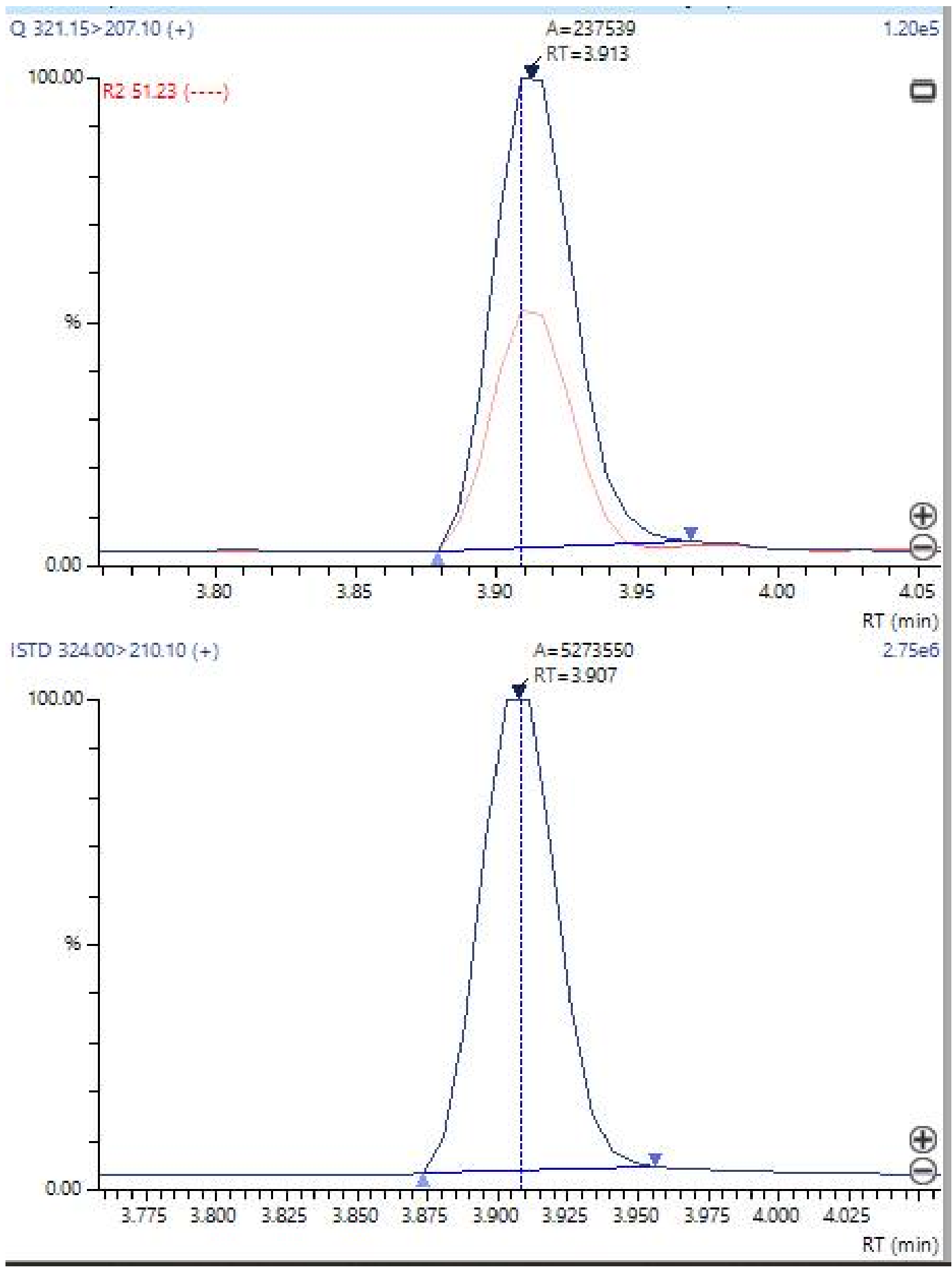

Figure 2. (A) LC-MS/MS plot of mycophenolic acid in the urine sample of Patient 1 above and the internal standard below. The graph shows a tracing in blue which is the quantifier ion (mass = 207.1) and a tracing in red which is the qualifier ion at mass $=159.1$. The peak below with only a single blue tracing is the tracing of the deuterium-labeled mycophenolic internal standard (mass = 210.1). The mycophenolic acid internal standard has a virtually identical retention time to mycophenolic acid in the patient, but the quantifier ion is mass $=210.1$ because of three deuterium atoms in the internal standard; (B) LC-MS/MS plot of mycophenolic acid in the urine sample of Patient 2 . The upper graph of the patient shows a tracing in blue which is the quantifier ion (mass = 207.1) and a tracing in red which is the qualifier ion at mass $=159.1$. The peak below with only a single blue tracing is the tracing of the deuterium-labeled mycophenolic internal standard (mass = 210.1). 
Table 4. Testing of indoor air condensates collected from the office.

\begin{tabular}{ccccc}
\hline \multirow{2}{*}{ Sample } & \multirow{2}{*}{ RH \% } & T ${ }^{\circ} \mathbf{C}$ & \multicolumn{2}{c}{ Change in Cell Viability \%, Mean \pm stdev, $\boldsymbol{p}$} \\
\cline { 4 - 5 } & & & THP-1 Monocytes & THP-1 Macrophages \\
\hline Working room 1 & 30.8 & 21.4 & $22.26 \pm 20.81^{*}$ & $-9.54 \pm 1.25^{* * *}$ \\
\hline Sample 2 & 30.2 & 21.4 & $18.12 \pm 16.6$ & $-2.87 \pm 2.06^{*}$ \\
\hline Sample 3 & 30.6 & 21.6 & $7.66 \pm 10.70$ & $-6.26 \pm 2.40^{* * *}$ \\
\hline Sample 4 & 29.1 & 21.7 & $28.40 \pm 12.59^{* * *}$ & $-6.62 \pm 1.26^{* * *}$ \\
\hline
\end{tabular}

Patient 1 worked in room 1, sample 4 was taken close from working area of Patient 2. The toxicity of the condensates was tested at a 10\% concentration on THP- 1 monocytes and THP-1 macrophages. The results are normalized against control and expressed as \% change in cell viability, mean \pm stdev, as compared to the control Negative values refer to a decrease in cellular viability, positive values refer to an increase in mitochondrial activity or proliferation. Both are considered as adverse effects. Each was tested in six parallel samples. The statistically significant changes in viability are bolded and indicated as ${ }^{*} p<0.05$; and ${ }^{* * *} p<0.001$.

Table 5. Testing of indoor air condensates collected from the home of Patient 1 and the HHC. Toxicity of condensates on THP- 1 macrophage when tested at $10 \%$ and $25 \%$ concentrations. The methods and explanations are as in Table 4.

\begin{tabular}{|c|c|c|c|c|}
\hline \multirow[t]{2}{*}{ Sample } & \multirow{2}{*}{ RH \% } & \multirow{2}{*}{$\mathbf{T}^{\circ} \mathbf{C}$} & \multicolumn{2}{|c|}{$\begin{array}{c}\text { Change in THP-1 Macrophage Viability \%, } \\
\text { Mean } \pm \text { Stdev, } p \text { (Significance) }\end{array}$} \\
\hline & & & $10 \%$ Condensate & $25 \%$ Condensate \\
\hline $\begin{array}{l}\text { Dormitory 1st floor } \\
\text { (Patient } 1 \text { and HHC) }\end{array}$ & 35.6 & 22.4 & $-2.13 \pm 4.55$ & $-13.35 \pm 5.84^{* * *}$ \\
\hline $\begin{array}{l}\text { Bedroom (son) } \\
\text { 2nd floor }\end{array}$ & 37.8 & 22.2 & $1.78 \pm 3.02$ & $1.56 \pm 3.72$ \\
\hline $\begin{array}{l}\text { Bedroom (daughter) } \\
\text { 2nd floor }\end{array}$ & 38.7 & 22.0 & $6.33 \pm 10.30$ & $1.07 \pm 8.56$ \\
\hline $\begin{array}{l}\text { Living room } 2 \text { nd } \\
\text { floor (HHC worked } \\
\text { in this space) }\end{array}$ & 39.6 & 22.0 & $2.83 \pm 6.17$ & $4.50 \pm 4.65 *$ \\
\hline
\end{tabular}

\subsection{Microbiological Analysis and the Toxicity of the Cultured Microbial Colonies}

The microbial growth from the office gravel sample was abundant on all the plates: the total fungal colonies were $13,000 \mathrm{cfu} / \mathrm{g}$ on MEA and $3900 \mathrm{cfu} / \mathrm{g}$ on DG18, and the total bacterial colony count was $42,000 \mathrm{cfu} / \mathrm{g}$ on TGY. Penicillium and Acremonium sensu lato constituted $97 \%$ of the fungal colonies on MEA plates, and on DG18 plates $92 \%$ of colonies were only Acremonium sensu lato. The other fungi, namely Aspergillus section Aspergillus (formerly Eurotium), Aspergillus ochraceus group, Cladosporium and Trichoderma grew only as a few colonies. No Streptomyces were detected.

Altogether, 11 microbial colonies (10 fungi and one bacterium) out of 32 colonies tested were toxic to the cultured cells (Table 6). All 11 colonies were toxic in the boar sperm test, and four of them were also toxic to the BHK-21 cells. The species that were toxic in both tests belonged to the fungal genera Acremonium sensu lato, which grew on MEA plates, and Aspergillus section Aspergillus, which grew on DG18 plates. The fungi which were toxic in the boar sperm test were only from the Aspergillus ochraceus group, which grew on DG18 plates, as well as from several Penicillium species, which grew on DG18 or MEA plates. 
Table 6. Toxic colonies: A total of 32 colonies were tested for toxicity to cultured cells.

\begin{tabular}{ccccc}
\hline Sample & $\begin{array}{c}\text { Fungal Genus } \\
\text { or Group }\end{array}$ & Culture Plate & $\begin{array}{c}\text { Toxicity in } \\
\text { Sperm Test }\end{array}$ & $\begin{array}{c}\text { Toxicity in } \\
\text { BHK-Test }\end{array}$ \\
\hline Sample 2 & Penicillium & MEA & Toxic & No \\
\hline Sample 4 & Penicillium & MEA & Toxic & Toxic \\
\hline Sample 9 & $\begin{array}{c}\text { Acremonium } \\
\text { sensu lato }\end{array}$ & MEA & Toxic & Toxic \\
\hline Sample 16 & $\begin{array}{c}\text { Acremonium } \\
\text { sensu lato }\end{array}$ & MEA & Toxic & No \\
\hline Sample 18 & $\begin{array}{c}\text { Penicillium } \\
\text { Sample 19 }\end{array}$ & DG18 & Toxic & Nonicillium \\
\hline Sample 21 & $\begin{array}{c}\text { Aspergillus } \\
\text { ochraceus-group }\end{array}$ & DG18 & Toxic & No \\
\hline Sample 27 & $\begin{array}{c}\text { Aspergillus } \\
\text { ochraceus-group }\end{array}$ & DG18 & Toxic & Toxic \\
\hline Sample 28 & $\begin{array}{c}\text { Aspergillus } \\
\text { section } \\
\text { Aspergillus } \\
\text { (Eurotium) }\end{array}$ & $\begin{array}{c}\text { DG18, direct } \\
\text { cultivation }\end{array}$ & Toxic & Toxic \\
\hline Sample 29 & $\begin{array}{c}\text { Aspergillus } \\
\text { (Eurotium) }\end{array}$ & Dacterium & TG18, direct \\
cultivation & Toxic & Toxic \\
\hline
\end{tabular}

\section{Discussion}

This pilot study revealed the presence of mycotoxins in the urine of the occupants who had been exposed to toxic indoor air, and emphasizes that a urinalysis for mycotoxins, when combined with a careful patient history and medical check-up, is a valuable tool in the diagnosis of DMHS. Until today, exclusively gaseous and particle exposure of toxic indoor air has been investigated, but the condensed water component of the air has been largely overlooked [7,19]. Therefore, our condensed water approach followed by cytotoxicity assays provides a rationale of conducting a risk assessment producing a numerical outcome. Recently, a call for such health risk-based indoor air methods has been published [47]

We detected a high concentration of mycophenolic acid in the first and follow-up urine samples of the two occupants of the problematic office. Moreover, traces of mycophenolic acid in the condensed water sample were also evident. It is assumed that the content of mycophenolic acid would have been higher if the sample tubes been protected during their sampling, storage, transportation and analysis; unfortunately, this was not the case. The fungal species recovered from the office are a potential source of mycophenolic acid production. Although the amount of toxin might be small in terms of absolute values, the exposure is, however, significant because large volumes of indoor air are inhaled each day. This exposure is dependent on the relative humidity ( $\mathrm{RH} \%$ ) of the air, i.e., when the $\mathrm{RH} \%$ and temperature increases, the quantity of inhaled mycotoxins will increase. Toxins can also be inhaled along with fungal particles.

All occupants of this working community experienced symptoms that were compatible with the advanced SBS, or DMHS (Table 2). The mycotoxin profiles of the two occupants exposed to the same dampness microbiota were similar but were different from the profiles of two unrelated patients (Patients $X$ and $Y$, Table 3). Patients $X$ and $Y$ also suspected that they had been exposed to dampness microbiota. They had also complained of symptoms, but the composition of dampness microbiota at the species level in their 
homes or workplaces must have been different. Therefore, these patients were taken as putative disease-controls for Patients 1 and 2.

Mycotoxins are secondary metabolites, and their production is highly species specific. Although mycotoxin production is common among indoor and outdoor fungi, some species are not thought to be mycotoxin producers, for example Cladosporium spp. [48]. Mycophenolic acid can be produced by the genera Penicillium [27] and Aspergillus section Aspergillus (formerly Eurotium) [49]. It was observed that several Penicillium species grew abundantly from the gravel sample taken from the hollow area in the proximity to the office; this was a location from which there was an air flow into the office. Four of the tested Penicillium species were found to be toxic in the boar sperm test as was the Aspergillus section Aspergillus which also grew from the gravel samples; this mold was not only toxic in the boar sperm test but also in the BHK-21 test. Half of the colonies of Acremonium sensu lato, which was a fungal group thriving in the gravel sample, was also shown to be toxic in both tests. There are only a few reports on the mycotoxins produced by Acremonium species. For example, it has been demonstrated that Acremonium exuviarum isolated from the building material produce a toxin called acrebol [24].

Previously, fungal identification was very difficult but now DNA-aided identification has proved to be beneficial. Here, we used conventional identification techniques established for the standard operational procedure of the accredited laboratory. It has been reported that a few fungal species may produce mycophenolic acid [50] and the species identified in this study belonged to the potential producers of mycophenolic acid. Importantly, we collected indoor air water condensate samples from other moisture-damaged offices, and six out of ten were also positive for mycophenolic acid (data not published). These samples were also toxic in the THP- 1 tests. These findings suggest that mycophenolic acid is a common contaminant in Finnish moisture-damaged buildings.

The route of entry of mycotoxins into the body has been a topic of debate. For example, the urine of 3000 Swedish adolescents was recently analyzed with the presence of 35 different mycotoxins being identified [51]. It was speculated that children had been exposed by oral ingestion of contaminated foodstuffs. Instead, the exposure via indoor air was not considered although it is recognized that there are moisture-damaged buildings in Sweden and therefore the possibility of inhalation exposure should not have been excluded.

The oral intake of mycophenolate mofetil by Patients 1 and 2 was ruled out because they were not receiving any immunosuppressive medication. Taking into account the growth of potential mycophenolic acid producers in the office building, it does seem that the exposure occurred via inhalation of the office's air supply. Mycophenolate mofetil is a first-line immunosuppressive drug used in transplantation immunology [52]. It is used to inhibit the proliferation of $\mathrm{B}$ and $\mathrm{T}$ lymphocytes and to prevent graft rejection and is also administered in the therapy of lupus nephritis [53]. If our pilot results are corroborated in a larger trial, we may be able to provide mechanisms by which some individuals exposed to dampness microbiota often experience recurrent infections [3]. These infections point to a dysfunction of the individual's immune system. This can be either local through the inhibition of innate immunity of the cilia cells lining the mucosal epithelium, or systemic involving acquired immunity. Prolonged exposure to mycophenolic acid may further result in a dysregulation of immune checkpoints leading to uncontrolled cell proliferation e.g., cancer. We have already reported an epidemiological observation that a prolonged exposure to dampness microbiota is associated with higher oncological morbidity [10].

Another interesting finding emerging from this study was the excretion of citrinin by Patient 2. This toxin can be produced by Acremonium and Penicillium species [54]. Both genera grew abundantly from the gravel sample. Fungi of the A. ochraceus group are known to produce ochratoxin A (OTA) and this potent mycotoxin was detected in minor amounts in the urine of Patients 1 and 2. This fungus was present only as a few colonies on the agar plates.

OTA was found also in the urine of the HHC to Patient 1. This finding is consistent with the toxicological studies from the bedroom of both Patient 1 and the HHC (Table 5), 
however, no microbiological studies were undertaken in their home. The HHC worked from home in their apartment, whereas Patient 1 worked in the office building, in the tested room 1.

Ochratoxin and citrinin have been identified in raisins, coffee, cereals, wine and beer; enniatin and zearalenone have also been commonly detected in cereal product. The symptoms experienced by our occupants related to the workplace and their diets were unchanged. Therefore, the inhalation route of entry remains as a possible option. In our view, even minute amounts of mycotoxins inhaled from indoor air may be a potential health hazard, since the levels of inhaled mycotoxins are dependent on relative humidity ( $\mathrm{RH} \%)$ and temperature.

We performed the urinalysis twice in Patients 1 and 2 and detected changes in the levels of mycophenolic acid; in Patient 1, the concentration decreased, whereas in Patient 2 , it increased after 2.5 months. Many mycotoxins are better extracted and dissolved in relatively non-polar solvents thus leading to the assumption that they are soluble in fatty tissues (reviewed in [2]). Therefore, their excretion kinetics would be expected to depend on an individual's mass of body fat as well as their genetic background [55]. Unfortunately, we did not examine the home of Patient 2. We emphasize that it is important to compare the mycotoxin profiles of the occupants who have had similar exposures, since it is very likely that in persons exposed to the same ecological system, their mycotoxin profile will display similarities. As an example, Patient $Y$ (unrelated to the working community) excreted high levels of gliotoxin, whereas Patients 1 and 2 excreted mycophenolic acid, and the levels remained high in the follow-up.

The strength of this study is the comprehensive and holistic multidisciplinary approach to assessing not only the patients but also the environments where they lived and worked. The environment was studied not only by accepted conventional microbiological techniques but also by a novel indoor air condensation technique supported by the functional cytotoxicity tests.

The importance of this communication is the idea of adopting a holistic approach to help the occupants to identify health risks of indoor air e.g., due to the presence of molds. The cumulative or prolonged exposure to toxic indoor air will inevitably be detrimental when the reversible SBS will be transformed into an irreversible DMHS with the so-called loss of tolerance to many unrelated compounds. This may lead to the development of multiple chemical sensitivity (MCS), chronic fatigue syndrome (CFS), autoimmune diseases, debilitating neurological functions, and disturbances in peripheral nervous system, to mention only a few hazardous outcomes.

The limitations of this study are as follows: Firstly, we have investigated a small working community and therefore this study is a pilot. Secondly, we were unable to explicitly demonstrate that the condensate of the workplace indoor air contained the same mycotoxins as the urine from Patients 1 and 2, but the findings were suggestive that this was the case. In the future, it would be valuable to apply our holistic approach as presented in Figure 3 as a roadmap to explain the morbidity caused by toxic indoor air. This approach might prove beneficial to encourage collaboration and cooperation between the treating physicians, environmental scientists, public health care providers and insurance companies. 


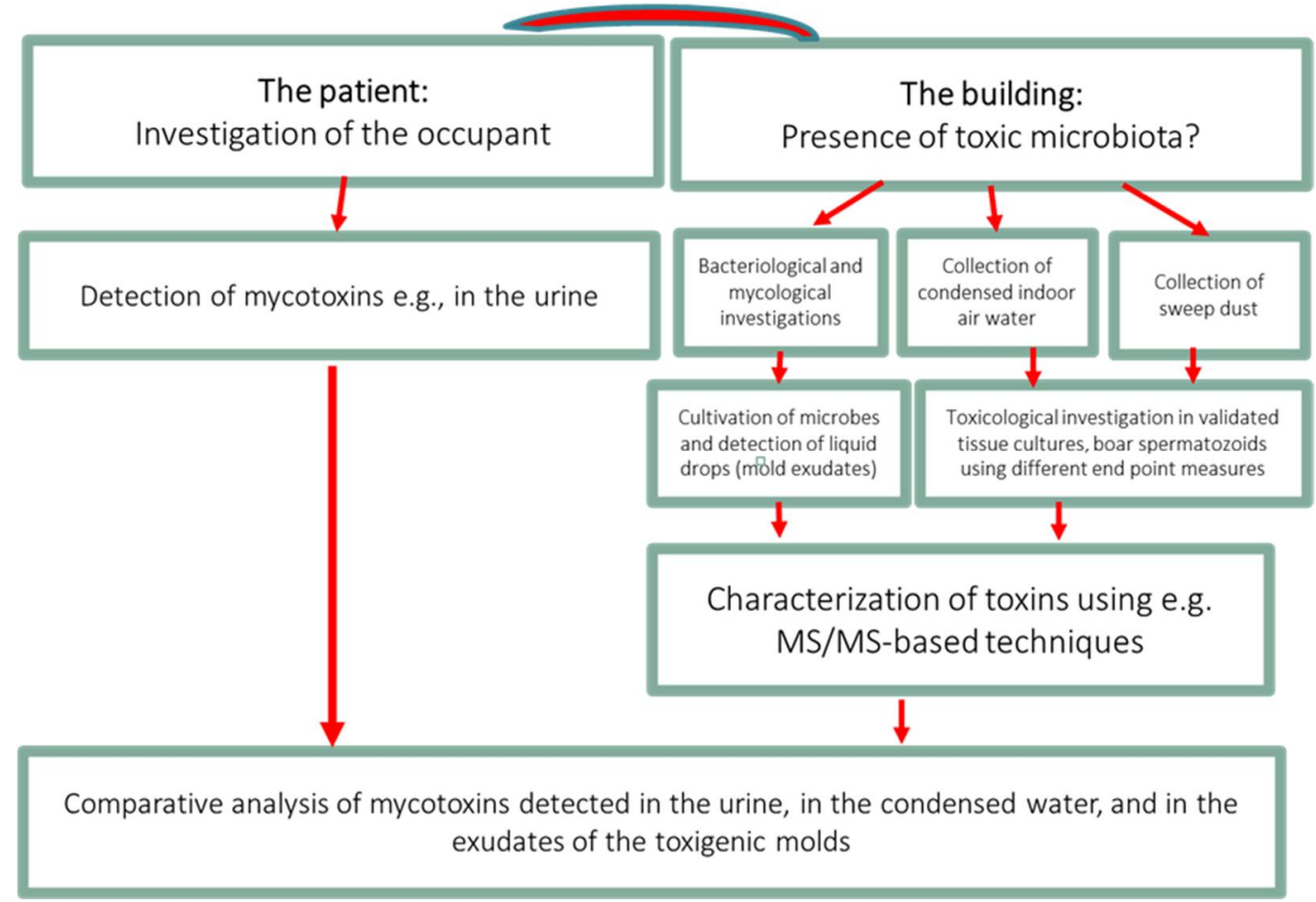

Figure 3. The roadmap to prove causality between the symptoms experienced by the occupant and the exposure to toxic indoor air.

\section{Conclusions}

We utilized a multidisciplinary, etiology-orientated approach for studying the morbidity associated with the toxic indoor air. We used (1) a technique for the collection of condensed indoor air water samples, (2) functional cytotoxicity tests to assess the toxicity of the indoor air condensate, (3) clinical evaluation of a working community exposed to poor indoor air, and (4) urinalysis for mycotoxin detection. We detected mycophenolic acid in the urine in both of the two studied occupants of the same moisture-damaged building. This potentially immunosuppressive mycotoxin can cause immune dysregulation that in the long run may be related to increased oncologic morbidity and susceptibility to infections.

Our recommendations are: 1. Examine the patients keeping in mind the possibility of a systemic and a multi-organ disease with high inter-individual variability; 2 . Perform appropriate laboratory tests for toxicosis, depending on the clinical symptoms; 3 . Undertake a urinalysis for mycotoxins; 4 . Study the patient's environment using microbiological and toxicological methods, especially techniques capable of detecting particulate matter, volatile organic compounds (VOC) of gases and indoor condensed water; 5 . Recommend that patients should avoid the inhalation of toxic indoor air and provide prompt rehabilitation. If possible, one should attempt to identify the source of the health risk and in this respect, it is recommended that the toxicity of the indoor air should be investigated and a urinalysis also performed on their household contacts (HHC).

Larger studies are needed to test the validity of our holistic approach.

Author Contributions: Conceptualization, K.V. and T.T.; methodology, M.T. and M.M.; software, M.M. and M.T.; validation, M.M. and T.H.; investigation, M.T. and M.M.; resources, T.H.; writingoriginal draft preparation T.T.; writing—review and editing, K.V., M.T., and M.M; visualization, K.V. and T.T; supervision, T.T.; project administration, T.H.; funding acquisition, T.H. All authors have read and agreed to the published version of the manuscript.

Funding: Sisäilmatutkimuspalvelut Elisa Aattela OY funded the assessment of toxicity of the condensed indoor air samples. M.M. and T.H. were funded by FICAM Institute, University of Tampere, Finland. 
Institutional Review Board Statement: These were waived in this study due to the fact that all of the cases provided written permission and that no invasive procedures were involved that could have harmed the participants.

Informed Consent Statement: Informed consent was obtained from all subjects involved in the study and no invasive methods were in use.

Data Availability Statement: Not applicable.

Acknowledgments: We thank Great Plains Laboratory for discussion and advice, all the patients who participated in this study and emeritus lecturer Ewen MacDonald for his help with the paper's style and grammar.

Conflicts of Interest: KV is owner of the SelexLab laboratory providing assays to the Great Plains Laboratory. The other authors' declarations of interest: none. The funders had no role in the design of the study; in the collection, analyses, or interpretation of data; in the writing of the manuscript, or in the decision to publish the results.

\section{References}

1. Salin, J.T.; Salkinoja-Salonen, M.; Salin, P.J.; Nelo, K.; Holma, T.; Ohtonen, P.; Syrjala, H. Building-related symptoms are linked to the in vitro toxicity of indoor dust and airborne microbial propagules in schools: A cross-sectional study. Environ. Res. 2017, 154, 234-239. [CrossRef] [PubMed]

2. Tuuminen, T.; Valtonen, V.; Vaali, K. Dampness and Mold Hypersensitivity Syndrome as an Umbrella for Many Chronic Diseases-The Clinician's Point of View, 2nd ed.; Science Direct: Reference Module in Earth Systems and Environmental Sciences; Elsevier: Amsterdam, Netherlands, 2019.

3. Valtonen, V. Clinical Diagnosis of the Dampness and Mold Hypersensitivity Syndrome: Review of the Literature and Suggested Diagnostic Criteria. Front. Immunol. 2017, 8, 951. [CrossRef] [PubMed]

4. Hyvonen, S.; Lohi, J.; Tuuminen, T. Moist and Mold Exposure is Associated with High Prevalence of Neurological Symptoms and MCS in a Finnish Hospital Workers Cohort. Saf. Health Work 2020, 11, 173-177. [CrossRef] [PubMed]

5. Hyvönen, S.; Poussa, T.; Lohi, J.; Tuuminen, T. High prevalence of neurological sequelae and multiple chemical sensitivity among occupants. Arch. Environ. Occup. Health 2020, 76, 145-151. [CrossRef]

6. Vornanen-Winqvist, C.; Jarvi, K.; Andersson, M.A.; Duchaine, C.; Letourneau, V.; Kedves, O.; Kredics, L.; Mikkola, R.; Kurnitski, J.; Salonen, H. Exposure to indoor air contaminants in school buildings with and without reported indoor air quality problems. Environ. Int. 2020, 141, 105781. [CrossRef]

7. Hyvönen, S.M.; Lohi, J.J.; Räsänen, L.A.; Heinonen, T.; Mannerström, M.; Vaali, K.K.; Tuuminen, T. Association of toxic indoor air with multi-organ symptoms in pupils attending a moisture-damaged school in Finland. Am. J. Clin. Exp. Immunol. 2020; in press.

8. Salin, J.; Ohtonen, P.; Syrjala, H. Teachers' work-related non-literature-known building-related symptoms are also connected to indoor toxicity: A cross-sectional study. Indoor Air 2021. Available online: https://onlinelibrary.wiley.com/doi/full/10.1111/ina. 12822 (accessed on 21 November 2021). [CrossRef]

9. Tuuminen, T. The Roles of Autoimmunity and Biotoxicosis in Sick Building Syndrome as a "Starting Point" for Irreversible Dampness and Mold Hypersensitivity Syndrome. Antibodies 2020, 9, 26. [CrossRef]

10. Tuuminen, T.; Rinne, K.S. Severe Sequelae to Mold-Related Illness as Demonstrated in Two Finnish Cohorts. Front Immunol. 2017, 8, 382. [CrossRef]

11. Lu, R.; Pørneki, A.D.; Lindgreen, J.N.; Li, Y.; Madsen, A.M. Species of Fungi and Pollen in the PM1 and the Inhalable Fraction of Indoor Air in Homes. Atmosphere 2021, 12, 404. [CrossRef]

12. Castagnoli, E.; Marik, T.; Mikkola, R.; Kredics, L.; Andersson, M.A.; Salonen, H.; Kurnitski, J. Indoor Trichoderma strains emitting peptaibols in guttation droplets. J. Appl. Microbiol. 2018, 125, 1408-1422. [CrossRef] [PubMed]

13. Salo, M.J.; Marik, T.; Mikkola, R.; Andersson, M.A.; Kredics, L.; Salonen, H.; Kurnitski, J. Penicillium expansum strain isolated from indoor building material was able to grow on gypsum board and emitted guttation droplets containing chaetoglobosins and communesins A, B and D. J. Appl. Microbiol. 2019, 127, 1135-1147. [CrossRef] [PubMed]

14. Andersson, M.A.; Salo, J.; Kedves, O.; Kredics, L.; Druzhinina, I.; Kurnitski, J.; Salonen, H. Bioreactivity, Guttation and Agents Influencing Surface Tension of Water Emitted by Actively Growing Indoor Mould Isolates. Microorganisms 2020, 8, 1940. [CrossRef]

15. Gareis, M.; Gareis, E.M. Guttation droplets of Penicillium nordicum and Penicillium verrucosum contain high concentrations of the mycotoxins ochratoxin A and B. Mycopathologia 2007, 163, 207-214. [CrossRef] [PubMed]

16. Gareis, M.; Gottschalk, C. Stachybotrys spp. and the guttation phenomenon. Mycotoxin Res. 2014, 30, 151-159. [CrossRef] [PubMed]

17. Rahmani, A.; Jinap, S.; Soleimany, F. Qualitative and Quantitative Analysis of Mycotoxins. Compr. Rev. Food Sci. Food Saf. 2009, 8, 202-251. [CrossRef] [PubMed]

18. Salo, J. Development of Analytical Methods for Assaying Metabolites of Molds in Buildings; Aalto University: Espoo, Finland, 2014.

19. Mannerström, M.; Toimela, T.; Ahoniemi, J.; Makiou, A.S.; Heinonen, T. Cytotoxicity of Water Samples Condensed from Indoor Air: An Indicator of Poor Indoor Air Quality. Appl. Vitr. Toxicol. 2020, 6, 120-130. [CrossRef] 
20. Andersson, M.A.; Mikkola, R.; Rasimus, S.; Hoornstra, D.; Salin, P.; Rahkila, R.; Heikkinen, M.; Mattila, S.; Peltola, J.; Kalso, S.; et al. Boar spermatozoa as a biosensor for detecting toxic substances in indoor dust and aerosols. Toxicol. Vitr. 2010, 24, $2041-2052$. [CrossRef]

21. Castagnoli, E.; Salo, J.; Toivonen, M.S.; Marik, T.; Mikkola, R.; Kredics, L.; Vicente-Carrillo, A.; Nagy, S.; Andersson, M.T.; Andersson, M.A.; et al. An Evaluation of Boar Spermatozoa as a Biosensor for the Detection of Sublethal and Lethal Toxicity. Toxins 2018, 10, 463. [CrossRef]

22. Mikkola, R.; Andersson, M.A.; Hautaniemi, M.; Salkinoja-Salonen, M.S. Toxic indole alkaloids avrainvillamide and stephacidin B produced by a biocide tolerant indoor mold Aspergillus westerdijkiae. Toxicon 2015, 99, 58-67. [CrossRef]

23. Salo, J.M.; Kedves, O.; Mikkola, R.; Kredics, L.; Andersson, M.A.; Kurnitski, J.; Salonen, H. Detection of Chaetomium globosum, $\mathrm{Ch}$. cochliodes and Ch. rectangulare during the Diversity Tracking of Mycotoxin-Producing Chaetomium-Like Isolates Obtained in Buildings in Finland. Toxins 2020, 12, 443. [CrossRef] [PubMed]

24. Andersson, M.A.; Mikkola, R.; Raulio, M.; Kredics, L.; Maijala, P.; Salkinoja-Salonen, M.S. Acrebol, a novel toxic peptaibol produced by an Acremonium exuviarum indoor isolate. J. Appl. Microbiol. 2009, 106, 909-923. [CrossRef] [PubMed]

25. Muth, W.L.; Nash, C.H., 3rd. Biosynthesis of mycophenolic acid: Purification and characterization of S-adenosyl-L-methionine: Demethylmycophenolic acid O-methyltransferase. Antimicrob. Agents Chemother. 1975, 8, 321-327. [CrossRef] [PubMed]

26. Puel, O.; Tadrist, S.; Galtier, P.; Oswald, I.P.; Delaforge, M. Byssochlamys nivea as a source of mycophenolic acid. Appl. Environ. Microbiol. 2005, 71, 550-553. [CrossRef]

27. Vinokurova, N.G.; Ivanushkina, N.E.; Kochkina, G.A.; Rinbasarov, M.U.; Ozerskaia, S.M. Production of mycophenolic acid by fungi of the genus Penicillium link. Prikl. Biokhim. Mikrobiol. 2005, 41, 95-98. [CrossRef]

28. Bentley, R. Mycophenolic Acid: A one hundred year odyssey from antibiotic to immunosuppressant. Chem. Rev. 2000, 100, 3801-3826. [CrossRef]

29. Regueira, T.B.; Kildegaard, K.R.; Hansen, B.G.; Mortensen, U.H.; Hertweck, C.; Nielsen, J. Molecular basis for mycophenolic acid biosynthesis in Penicillium brevicompactum. Appl. Environ. Microbiol. 2011, 77, 3035-3043. [CrossRef]

30. Ismaiel, A.A.; Ahmed, A.S.; El-Sayed el, S.R. Optimization of submerged fermentation conditions for immunosuppressant mycophenolic acid production by Penicillium roqueforti isolated from blue-molded cheeses: Enhanced production by ultraviolet and gamma irradiation. World J. Microbiol. Biotechnol. 2014, 30, 2625-2638. [CrossRef]

31. Lafont, P.; Debeaupuis, J.P.; Gaillardin, M.; Payen, J. Production of mycophenolic acid by Penicillium roqueforti strains. Appl. Environ. Microbiol. 1979, 37, 365-368. [CrossRef]

32. van Oss, C.J.; Giese, R.F.; Docoslis, A. Hyperhydrophobicity of the Water-Air Interface. J. Dispers. Sci. Technol. 2005, 26, 585-590. [CrossRef]

33. Salonen, H.; Heinonen, T.; Mannerström, M.; Jackson, M.; Andesson, M.; Mikkola, R.; Kurnitski, J.; Khurshid, S.; Novoselac, A.; Corsi, R. Assessing indoor air toxicity with condensate collected from air using the mitochondrial activity of human BJ fibroblasts and THP-1 monocytes. In Proceedings of the Conference of International Society of Indoor Air Quality and Climate, Philadelphia, PA, USA, 22-27 July 2018.

34. Mosmann, T. Rapid colorimetric assay for cellular growth and survival: Application to proliferation and cytotoxicity assays. $J$ Immunol. Methods 1983, 65, 55-63. [CrossRef]

35. Ost, M.; Keipert, S.; Klaus, S. Targeted mitochondrial uncoupling beyond UCP1-The fine line between death and metabolic health. Biochimie 2017, 134, 77-85. [CrossRef] [PubMed]

36. ISO Standard. Indoor Air-Part 21: Detection and Enumeration of Moulds. Sampling from Materials; ISO 16000-21; ISO: Geneva, Switzerland, 2013.

37. American Public Health Association; American Water Works Association. Standard Methods for the Examination of Water and Wastewater; APHA: Washington, DC, USA, 1980; Volume 15.

38. Valvira, Asumisterveysasetuksen soveltamisohje, Osa IV. In Asumisterveysasetus §20; Updated 2020; National Supervisory Authority for Welfare and Health, Valvira: Helsinki, Finland, 2016; Volume Ohje 8/2016, Available online: https:/ /www.valvira.fi/ documents/14444/261239/Asumisterveysasetuksen+soveltamisohje+osa+IV.pdf/cdfaaa39-d2e5-4bd6-b9e9-6d9c0f60bff6 (accessed on 21 November 2021).

39. Pessi, A.-M.; Jalkanen, K. Laboratorio-Opas, 1st ed.; Suomen Ympäristö-ja Terveysalan Kustannus Oy: Pori, Finland, 2018.

40. Gravesen, S.; Frisvad, J.C.; Samson, R.A. Microfungi; Special-Trykkeriet Viborg a/s: Copenhagen, Denmark, 1994.

41. Institut Scientifique de Sante Publique \& BCCM. Moulds in the Indoor Environment and Outdoor; Institut Scientifique de Sante Publique \& BCCM: Bruxelles, Belgium, 2017.

42. Bequin, H. Moisiss ures de L'Environnement Intérieur et Extérieur; Section of Mycology \& Aerobiology, Ed.; Institut Scientifique de Sante Publique: Bruxelles, Belgium, 2004.

43. Larone, D.H. Medically Important Fungi. A Guide to Identification, 2nd ed.; American Society for Microbiology: Washington, DC, USA, 1993.

44. Klich, M.A. Identification of Common Aspergillus Species; CAB Direct: Wageningen, The Netherlands, 2002.

45. Rasimus, S.; Mikkola, R.; Andersson, M.A.; Teplova, V.V.; Venediktova, N.; Ek-Kommonen, C.; Salkinoja-Salonen, M. Psychrotolerant Paenibacillus tundrae isolates from barley grains produce new cereulide-like depsipeptides (paenilide and homopaenilide) that are highly toxic to mammalian cells. Appl. Environ. Microbiol. 2012, 78, 3732-3743. [CrossRef] [PubMed] 
46. Bencsik, O.; Papp, T.; Berta, M.; Zana, A.; Forgo, P.; Dombi, G.; Andersson, M.A.; Salkinoja-Salonen, M.; Vagvolgyi, C.; Szekeres, A. Ophiobolin A from Bipolaris oryzae perturbs motility and membrane integrities of porcine sperm and induces cell death on mammalian somatic cell lines. Toxins 2014, 6, 2857-2871. [CrossRef]

47. Morawska, L.; Allen, J.; Bahnfleth, W.; Bluyssen, P.M.; Boerstra, A.; Buonanno, G.; Cao, J.; Dancer, S.J.; Floto, A.; Franchimon, F.; et al. A paradigm shift to combat indoor respiratory infection. Science 2021, 372, 689-691. [CrossRef]

48. Nielsen, K.F.; Frisvad, J.C. Mycotoxins on Building Materials; Wageningen Academic Publishers: Wageningen, The Netherlands, 2011.

49. Seguin, V.; Gente, S.; Heutte, N.; Verite, P.; Kientz-Bouchart, V.; Sage, L.; Goux, D.; Garon, D. First report of mycophenolic acid production by Eurotium repens isolated from agricultural and indoor environments. World Mycotoxin J. 2014, 7, $321-328$. [CrossRef]

50. Samson, R.A.; Houbraken, J.; Thrane, U.; Frisvad, J.C.; Andersen, B. Food and Indoor Fungi; Westerdijk Fungal Biodiversity Institute: Utrecht, The Netherlands, 2019; Volume 2, p. 481.

51. Warensjo Lemming, E.; Montano Montes, A.; Schmidt, J.; Cramer, B.; Humpf, H.U.; Moraeus, L.; Olsen, M. Mycotoxins in blood and urine of Swedish adolescents-possible associations to food intake and other background characteristics. Mycotoxin Res. 2020, 36, 193-206. [CrossRef]

52. van Gelder, T.; Hesselink, D.A. Mycophenolate revisited. Transpl. Int. 2015, 28, 508-515. [CrossRef]

53. Mok, C.C. Mycophenolate mofetil for lupus nephritis: An update. Expert Rev. Clin. Immunol. 2015, 11, 1353-1364. [CrossRef]

54. Johannessen, L.N.; Nilsen, A.M.; Lovik, M. The mycotoxins citrinin and gliotoxin differentially affect production of the proinflammatory cytokines tumour necrosis factor-alpha and interleukin-6, and the anti-inflammatory cytokine interleukin-10. Clin. Exp. Allergy 2005, 35, 782-789. [CrossRef]

55. Genuis, S.J.; Kyrillos, E. The chemical disruption of human metabolism. Toxicol. Mech. Methods 2017, 27, 477-500. [CrossRef] [PubMed] 